\title{
Please remind me: A history of the Japanese particle of recollection kke
}

\author{
John Bundschuh*
}

\begin{abstract}
The Japanese sentence-final particle $k k e$ is a marker of epistemic modality with evidential and mirative overtones. Its most common application is indexing the uncertainty of one's recollection in interrogative sentences, but in declarative sentences it indexes a reaffirmation of the certainty of the utterance. This study traces the grammatical development of kke from the older Japanese perfect auxiliary -kyeri, citing examples from 8th-century Japanese through today. Through examining $k k e$ 's diachrony, it provides evidence that modal sentence-final particles can develop from auxiliaries when the contexts in which they are used become restricted over time.
\end{abstract}

Keywords. Japanese; sentence-final particles; historical linguistics; epistemic modality; degrammaticalization

1. Introduction. The Japanese sentence-final particle $k k e$ is a marker of epistemic modality with evidential and mirative overtones. Its most common application is indexing uncertainty in interrogative sentences (Matahira 1996, Ikeya 2012, Ma 2017), which Hayashi (2012) calls the epistemic state of "uncertainty in recollection." It can be used in both Wh-questions, as in example (1), and polar questions, as in example (2) below.
(1) kyō-no tenki-wa nan da kke
today-GEN weather-TOP what COP KKE
'What is today's weather? ((I don't recall. Please remind me.))'
(2) kyō-wa ame da kke
today-TOP rain $\mathrm{COP} \mathrm{KKE}$
'Is it raining today? ((I don't recall. Please remind me.))'

These interrogative uses of kke have led Sauerland and Yatsushiro (2017) to call kke-marked sentences such as examples (1) and (2) "remind-me presuppositions."

On the other hand, $k k e$ is used in declarative sentences to index a reaffirmation of the certainty of the predicate (Matahira 1996), as in example (3) below:
$\begin{array}{lll}\text { kyō-wa ame da } & \text { kke } \\ \text { today-TOP rain } & \text { COP } & \text { KKE }\end{array}$
'((I now recall the fact that $))$ It is raining today.'

Declarative uses of kke such as example (3) mark the sentence's proposition as certain due to an information-update process. More specifically, it marks the retrieval of fact that one previously knew. Matahira (1996) describes this use as either a secondhand evidential or mirative - the former if one sees a wet umbrella on the way to the door (inferred) or has just been informed by an interlocutor (reported), the latter if uttered when looking out the window to see the rain falling - which is a common mirative extension of secondhand evidentials used in firsthand contexts (Aikhenvald 2004). Although Japanese has numerous sentence-final particles that index

\footnotetext{
* My thanks to the audience of LSA2021 for feedback and Charles Quinn for detailed comments on this manuscript. Author: John Bundschuh, The Ohio State University (bundschuh.8@osu.edu).
} 
epistemic modality, $k$ ke is unique in its historical development from an auxiliary, or inflecting suffix.

The sentence-final particle $k k e$ found in Japanese today developed from the Old Japanese auxiliary -kyeri (Martin 1975, Frellesvig 2010). ${ }^{1}$ Quinn (1983) demonstrates -kyeri is an evidential modal that indexes externally established facts. Shinzato (1991) compares the evidentiality, temporality, and epistemicity of Early Middle Japanese -keri to Turkish - mış, finding that both index secondhand evidentiality, mirativity, perfect temporality, and non-integrated information. This paper examines the phonological, morphological, syntactic, and semantic changes of auxiliary -kyeri to standard Japanese sentence final particle kke, providing another example to the growing literature on the loosening of internal bonds between morphemes, a process often described as degrammaticalization (Hopper \& Traugott 2003, Norde 2009).

2. Diachrony of -kyeri $>$ kke. This section traces the grammatical development of auxiliary kyeri to sentence-final particle kke in today's standard Japanese, citing examples from 8thcentury Japanese through today, beginning with its theorized origins.

2.1. THEORIZED ORIGINS. The most widely accepted theory regarding the origin of -kyeri is from the participle of the verb 'come' ki being governed by the stative auxiliary -ari resulting in perfect -kyeri (Kasuga 1942, Vovin 2009).

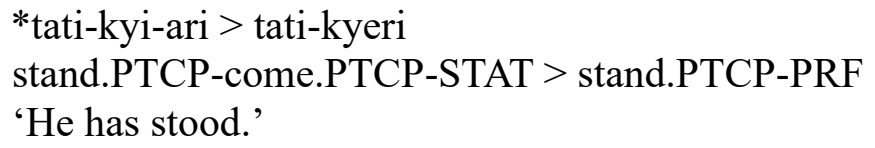

It is evident in the earliest sources of Japanese data that its phonology did not allow adjacent vowels, and there are no data to suggest this was not the case in its prehistory as well. Furthermore, the stative auxiliary -ari was productive in these earliest texts, and the assimilatory process we see in (4) of * Cyi-ari > Cyeri is what we find whenever -ari governs a participle.

2.2. OLD JAPANESE (CA. $8^{\mathrm{TH}}$ CENTURY CE). This is the earliest period from which we have concrete Japanese language data. In the earliest textual sources, the auxiliary -kyeri had the following morphological paradigm.

$$
\begin{aligned}
& \text { irrealis stem: } \quad \text {-kyera- } \\
& \text { conclusive form: }- \text { kyeri } \\
& \text { adnominal form: } \\
& \text { realis form: }
\end{aligned}
$$

Table 1. Inflectional Paradigm of Old Japanese - kyeri $^{2}$

\footnotetext{
1 Throughout this paper I follow the convention of using [y] to refer to what is more accurately [j] in the international phonetic alphabet.

2 Old Japanese predicate inflectional paradigms also had a participle, which -kyeri governed, and an imperative form. There are no instances of -kyeri in these forms in the data, which reflects its semantic range as a perfect, modal, or mirative, which are limited to non-imperative forms. Furthermore, many Western researchers, such as Vovin (2009) and Frellesvig (2010), describe a single morpheme -(i)kyer-governed by morphemes that index irrealis, conclusive, etc., rather than an auxiliary -kyeri with an inflectional paradigm. I follow the convention of using the conclusive, or unmarked sentence-final form, to refer to auxiliaries.
} 
In both Old Japanese and Early Modern Japanese, the irrealis stem is governed by modal and valence suffixes and auxiliaries. The CONCLUSIVE form marks finite predicates that do not refer to known discourse referents. The ADNOMINAL form both modifies nouns and, when standing alone, constitutes a nominalized finite predicate. The realis form marks referentialized non-finite predicates, which were most often governed by provisional or concessive suffixes.

By the time of its earliest attestations, -kyeri had undergone semantic broadening from its theorized origins as a perfect to index epistemic modality and mirativity. Cross-linguistically, perfects becoming semantically underspecified to index epistemicity often come to index indirect evidentiality as well (Bybee et al. 1993, Ivorski 1997, Lau \& Rooryck 2017). However, according to Frellesvig (2010:76), there are no data that suggest -kyeri indexed this category in its use throughout the Old Japanese corpus. ${ }^{3}$ Examples (5) through (7) below display -kyeri's varied use during this period.

(5) taputwoku ari-kyeri ${ }^{4}$

revered exist.PTCP-KYERI

'((I realize that)) I feel reverence.'

yoso-ni mukyi-kyeri ${ }^{5}$

different-LOC face.PTCP-KYERI

'((The fact is that)) it is facing a different way.'

sugi-ni-kyera-zu ya $^{6}$

pass.PTCP-PFV.PTCP-KYERI.IRR-NEG SFP

'Has it not passed? ((Indeed, it has!))'

Example (5), from ca. $712 \mathrm{CE}$, displays the mirative use of -kyeri. Examples (6) and (7), both from ca. $759 \mathrm{CE}$, display the auxiliary's epistemic and perfect uses, respectively. Some scholars argue -kyeri had already lost its perfect meaning by the earliest textual sources, but examples such as (7), in which it is governed by a negation suffix, although few in number, suggest it still retained its temporal index at this stage of the language.

2.3. EARLY MidDLE JAPANESE (CA. 9TH-12TH CENTURIES CE). One of the defining sound changes in the language from Old Japanese to Early Middle Japanese is the loss of post-consonantal /y/ before /e/ ca. $800 \mathrm{CE}$ (Frellesvig 2010: 206), which resulted in -kyeri becoming -keri.

Furthermore, -keri was no longer a primary index of perfect temporality, likely due to the nowprimary status of its epistemic use on the one hand, and the newer, default perfect -tari, on the other. The auxiliary -tari was formed early in the period from the participial form of the exoactive perfective auxiliary, -te, followed by stative ari (-te ari $>$-tari). The loss of -kyeri's perfect temporality resulted in the loss of its irrealis stem, as the factuality of predicates governed by -keri could no longer be hedged grammatically, as in example (7). This morphological change resulting from its semantic shift led to the following paradigm.

\footnotetext{
3 We do find, however, an apparent evidential extension used in later narrative fiction, which is discussed in the following subsection.

4 Poem 7 of the Kojiki (Yamaguchi \& Kōnoshi 1997:137).

5 Poem 216 of the Man'yōshü (Kojima et al. 1994:146).

6 Poem 221of the Man'yōshū (Kojima et al. 1994: 149).
} 
conclusive form: -keri

adnominal form: -keru

realis form: $\quad$-kere

Table 2. Inflectional Paradigm of Early Middle Japanese -keri

The following two examples are representative of -keri's sentence-level semantics during the period.

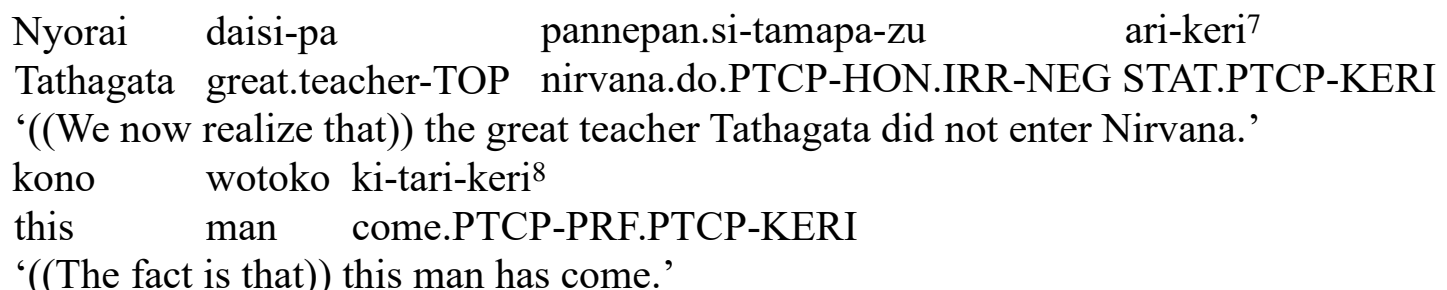

'((The fact is that)) this man has come.'

Example (8) demonstrates -keri's mirative use. Example (9) depicts -keri's primary use throughout the period as an epistemic modal, marking the predicate as an externally established fact (Quinn 1983).

Early Middle Japanese -keri was often used in narration governing predicates that depicted events not experienced by the narrator. This has led Early Middle Japanese -keri to be described as a marker of second-hand evidentiality as well, but Quinn (1983) argues that it was -keri's primary epistemic meaning as an index of externally established fact that motivated its use when direct supporting evidence for asserting a situation was low. That is, in discourse contexts where a speaker wanted to present information as factual but lacked direct evidence, such as in narrating events not witnessed firsthand, or when introducing a previously unnarrated situation as already having happened, the statement could be linguistically and epistemically bolstered using the modal -keri. Its use in narration reminded the audience of the narrator's presence and 'represent[ed] a legitimizing element of affirmation for [Early Middle Japanese] discourse through which the discourse ground[ed] itself' (Okada 1991:42).

There seems to be cross-linguistic evidence of speakers employing a single morpheme for both narrative authority and previously unassimilated or unintegrated facts. Data on the Western Apache 'past deferred realization' particle lé $k^{\prime} e h$ from de Reuse (2003) suggest that it may index indirect evidentiality, mirativity, or epistemic modality depending on the context. This particle is required at the end of every sentence in narration as a marker of narrative authority, leading Aikhenvald to write the following.

Employing lé, $k^{\prime} e h$ in a traditional narrative indicates that the evidence is not firsthand. At the same time it emphasizes that the storyteller is aware of their authority as narrator and often as author. This awareness can be considered a facet of the 'deferred' realization meaning of the particle lé, $k^{\prime} e h$ and provides a bridge between its two seemingly distinct meanings - as a marker of a narrative genre and as an indicator of post-factum realization of what the witnessed thing actually was. (Aikhenvald 2004:204)

Although these parallels exist, there are notable differences between Early Middle Japanese -keri and Western Apache lé, $k^{\prime} e h$. Firstly, in narratives -keri was often used as a framing device in

\footnotetext{
${ }^{7}$ From a ca. 830 Japanese translation of the Golden Light Sutra (Kasuga 1942:19).

8 From ca. 900 Ise monogatari (Katagiri et al. 1994:139).
} 
orientations and conclusions rather than in every line of the story. Secondly, although they both had mirative extensions, unlike the primarily evidential lé $k^{\prime} e h,-k e r i$ was primarily epistemic. Finally, -keri was not a particle, but an inflecting part of predicate morphology. It was often employed as a modal indexing factuality in noun-modifying relative clauses, as demonstrated in example (10) in the following subsection.

2.4. LATE MidDLE JAPANESE (CA. 13TH-16TH CENTURIES CE). It should be noted here that all changes described for Late Middle and Early Modern Japanese are specifically regarding representations of the spoken language. The language of Early Middle Japanese had become codified as Japan's primary written register, leading to numerous tokens of -keri based on its perceived $10^{\text {th }}$-century-CE semantics and pragmatics in texts composed up to and through the early $20^{\text {th }}$ century $\mathrm{CE}$. The phonological and morphological changes from inflecting suffix -keri to noninflecting suffix - $k$ ke that are theorized to have taken place during this period are discussed briefly in Yoshida (1971:231) and Martin (1975:938) and expanded upon in Frellesvig (2010:331,353).

Firstly, a defining paradigmatic shift that occurred throughout Japanese predicate structure at the onset of Late Middle Japanese was the merger of the conclusive and adnominal forms ca. 1200 CE (Frellesvig 2010:328-30). This change was likely due to the prevalence of adnominal forms in subordinate clauses and before sentence-final particles that caused nominalizations due to syntactic rules, which we see in the following examples.
go-kuyō
ari-keru
fi, mairite ogami-keru-ni, ${ }^{9}$
HON-Buddhist.service exist-KERI day go-GER pray-KERI-LOC
'when he ((certainly)) went to pray on a day there ((certainly)) was a Buddhist service,'

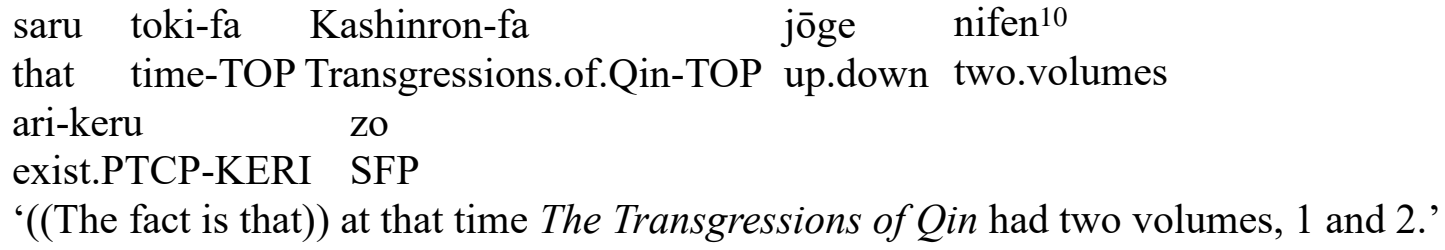

Example (10 depicts the epistemic use of -keri in two successive subordinate clauses. Here I use '((certainly))' to approximate -keri's significance as it is employed by the narrator to mark the factuality of the events of the day. Example (11), shows the adnominal form -keru being used due to the clause's nominalization in forming a situation-characterizing referential predicate (analogous to today's /finite clause + nominal no $(d a)$ / extended predicate), which is predicated with the quasi-copula $z o$.

There came to be in Japanese a pattern of clause nominalization similar to what is seen with the past passive participle in Sanskrit, which came to be used as the main verb in the sentence regardless of it being a nominalized form. Likewise, in Japanese adnominally inflected, ad-hoc nominal predicates were reinterpreted and took the mantle of the standard finite form from the conclusive form, which caused the following change in -keri's paradigm.

\footnotetext{
9 Yanase (1964:170) citing Kamo no Chōmei. 1215. Hosshinshū.

${ }^{10}$ Muromachi Jidaigo Jiten Henshū Iinkai (1985:968) citing Tōgen, Zuisen. 1477. Shikishō Vol. 4.
} 
conclusive form: -keri

adnominal form: -keru $>$ imperfective form: -keru

realis form: -kere realis stem: -kere

Table 3. Inflectional paradigm change:

Early Middle Japanese -keri to Late Middle Japanese -keru

Auxiliary -keru underwent a series of morphophonological changes throughout the Late Middle Japanese period, resulting in it becoming an uninflecting suffix -kke. Below I lay out these changes with -keri governing the perfect auxiliary -taru, which underwent parallel changes during the period in becoming the perfective suffix - $t a$ (see also Yoshida 1971:231 and Frellesvig 2010:331).

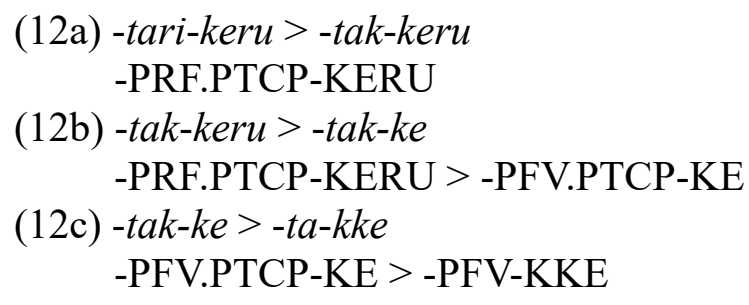

In (12a) we see a common assimilation of the final mora of participial forms to the following consonant, in this case $/ \mathrm{ri} />/ \mathrm{k} /$. Changes (12b) and (12c) likely cooccurred due to a deletion of final -ru in auxiliaries (Frellesvig 2010: 353). With -taru becoming -ta and -keru becoming -ke, the morphological status of the first $/ \mathrm{k} /$ in predicates ending in -takke became unclear. Perfective suffix - $t a$ was, and remains, highly productive, and thus the more restricted - $k e$ underwent reanalysis to become $-k k e$. This would set this suffixal form free and on the path to clitic, or particle, status.

By the end of Late Middle Japanese, -kke underwent a morpho-syntactic constraint as well in that it could only govern perfective $-t a$ and copula $d a$. This is likely due to two reasons. Firstly, all Early Middle Japanese auxiliaries that governed the participle, other than -tari $>$-ta and -keri $>-k k e$, were lost, and only -tari continued to govern the participle. Secondly, -kke was commencing a semantic change that remained incomplete until the modern period. It was beginning to surrender its function of indexing externally established facts to a different but still epistemically modal use, that of indexing the recollection of established facts. So why the constraint of applying only to perfective predicates and nominals predicated by the copula?

These two predicate types have in common referable entities - since they express situations and events that have already occurred and identities taken to exist as they are asserted. The referability of both is apparent and thus they constitute matters subject to recall- 'there' for the recalling. However, this semantic shift was not complete by the end of the Late Middle Japanese period. Although epistemic suffix -kke, unlike its "parent" -keru, was no longer used in a relative clause to modify a noun — contrasting with what we see in example (10) above - it was still used in concessive clauses linked to the next clause by particle $g a$, as in example (16) below.

Finally, it must be acknowledged that most of the changes depicted in this subsection are reconstructions that are to varying extents theoretical, and not reinforced with empirical data. There are two primary reasons for the lack of -keri $>-k k e$ data in Late Middle Japanese. Firstly, written sources from the earlier half of the period used predominantly archaic forms in writing, even in quoted representations of dialog (Frellesvig 2010:297). Secondly, by the end of the Late Middle Japanese period, -keri was lost from the Kyoto-area dialect where it had been in evidence 
in texts from Old Japanese through Late Middle Japanese (Koyama 2003). Data of -kke from Early Modern Japanese are from the eastern region centered around Tokyo. The nexus of political power, however, shifted from Kyoto to Tokyo (called Edo at the time) during this period, meaning -keri $>-k k e$ remained part of the language of the center of power.

2.5. EARLY MODERN JAPANESE (CA. 17TH-19TH CENTURIES CE). The earliest example of -kke cited in the Nihon kokugo daijiten is in an essay penned in the capital ca. $1724 \mathrm{CE}$ in which the author is describing non-standard language use in his regional dialect.

The province of Kai is a place where we use a rare expression [. . .] We say kke to mean 'I realize it was so.' We use this by attaching it at the end of an expression such as Só da kke ['((I realize that $))$ it is so.'] An expression comes together, and we attach this kke. ${ }^{11}$

This suggests (-)kke was not considered a sentence-final particle (SFP) in the standard language during the first half of the period. By the latter half, this use of kke as a SFP, as opposed to as a suffix, came to be used, albeit rarely, in the language of the capital, as we see in the following example.

$\begin{array}{llll}\text { otomisan } & \text { yagenbori-kara kotodzuke-ga at-ta } k^{12} \\ \text { Otomi.HON Yagenbori-FROM message-NOM exist-PFV KKE } \\ \text { 'Otomi, was there a message from Yagenbori? ((I don't recall. Please remind me)).' }\end{array}$

The 'remind-me' use of $k k e$ in interrogative sentences, as we see in example (13), was still rare in the Early Modern Period (Shibutani 1999). Note also that the forms of the predicate and particle we see here are products of the shifts described in (12) in section 2.4 above (ari-tari-keri $>$ at-takkeru $>$ at-ta-kke) and - kke's subsequent, final break from predicate morphology, allowing it to mark a predicate as a target for a memory search (at-ta-kke $>$ at-ta kke). The following two examples are cited in Shibutani 1999.

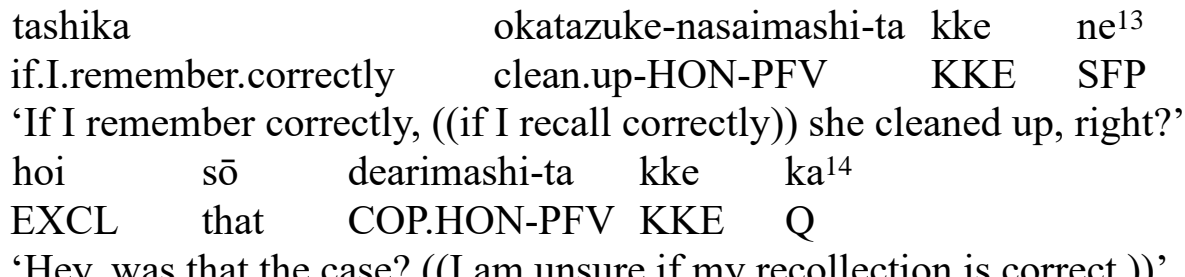

Example (14) presents a speaker marking their recalling a fact from their memory with SFP kke and confirming this with their interlocutor using the SFP ne. In example (15) the speaker is using $k k e$ to grammatically mark that they are seeking a reminder to help them recall a fact of which they are uncertain, made explicit with the interrogative marker $k a$. Although we find examples of $k k e$ as a sentence-final particle, we still find it phrase-finally during the Early Modern Period, suggesting it had yet to expand its scope across an entire utterance.

\footnotetext{
11 ke (2020) citing Yanagisawa, Kien. 1724. Hitorine Vol. 2.

12 takke (2020) citing Tanishi, Kingyo. 1777. Geisha yobu kodori.

13 Shibutani (1999:221) citing Shikitei, Sanba. 1810. Ukiyoburo Vol 2.

14 Shibutani (1999:221) citing Kyokusanjin. 1834.Kanamajiri Musume setsuyō Vol. 3.
} 
goku bimbō-no ko da-kke ga $^{15}$

very poor-GEN girl COP-KKE but

'((The fact is that $))$ she is a very poor girl but...'

This example, from $1836 \mathrm{CE}$, shows -kke used as an epistemic modal in a subordinate clause marked by conjunctive phrase-particle ga. Phrase-particle ga could (and still can) govern predicates with politeness marking, which suggests it can have scope over predicate components that index parameters of discourse interaction, much like sentence-final particles.

2.6. MODERN JAPANESE (20TH CENTURY CE-TODAY). Today the syntactic and semantic changes that were in progress in Early Modern Japanese are complete. Syntactially, suffix - kke is now sentence-final particle $k k e$ and thus now has sentence-level rather than clause-level scope.

Semantically, kke marks a recollection of a fact in declarative sentences and in interrogative ones in indicates "uncertainty in recollection" (Hayashi 2012), rather than indexing an externally established fact. Although kke can still be followed by other sentence-final particles, it is no longer governed by conjunctions such as ga as seen in (16). This has led Shibutani (1999) to note that, although Early Modern Japanese -kke could index a recollection based on searching one's memories, it still retained stronger characteristics of an epistemic modal than what we see in $k k e$ today. Examples of present-day kke followed by sentence-final particles yo, ne, and $k a$, drawn from Matahira (1996), are below.

$\begin{array}{lllll}\text { dare-ga sonna } & \text { koto it-ta } & \text { kke } & \text { yo } \\ \text { who-NOM that.kind.of } & \text { thing } & \text { say-PFV } & \text { KKE } & \text { SFP }\end{array}$

'Who said that kind of thing? ((I don't recall anyone doing so.))'

\begin{tabular}{|c|c|c|c|c|c|}
\hline $\begin{array}{l}\text { Tanaka-san } \\
\text { Tanaka-HON }\end{array}$ & $\begin{array}{l}\text { tte } \\
\text { TOP }\end{array}$ & $\begin{array}{l}\text { Tōkyō-shusshin } \\
\text { from.Tokyo }\end{array}$ & $\begin{array}{l}\text { dat-ta } \\
\text { COP-PFV }\end{array}$ & $\begin{array}{l}\text { kke } \\
\text { KKE }\end{array}$ & $\begin{array}{l}\text { ne } \\
\text { SFP }\end{array}$ \\
\hline \multicolumn{6}{|c|}{ 'Was Tanaka from Tokyo? ((If I recall correctly.))' } \\
\hline Tanaka-san & tte & Tōkyō-shusshin & dat-ta & kke & $\mathrm{ka}$ \\
\hline Tanaka-HON & TOP & from.Tokyo & COP-PFV & KKE & $\mathrm{Q}$ \\
\hline
\end{tabular}

Matahira argues that cases of kke yo, such as in (17), are only used in rhetorical questions with an incredulous stance; cases of kke ne, such as in (18), are seeking confirmation rather than new information; and cases of kke ka, such as in (19), are indexing doubt in their recollection. Although $k k e$ can be followed by these sentence-final particles, it cannot follow them. This is likely due to $k k e$ being a more speaker-oriented particle, in that it indexes the result of a speaker searching and confirming their own knowledge rather than indexing a stance taken toward one's interlocutor, as with the other sentence-final particles above. ${ }^{16}$ Although it is more sytactically bound to its predicate, that bond is not morphological.

Another token of evidence that kke is now a sentence-final particle rather than a suffix is its recent distributional expansion. Since its loss of inflection in the Late Middle Japanese period, as a suffix - $k k e$ was limited to governing perfective -ta or copula $d a$, which we see in all the data of the Early Modern Period. Even recently published editions of authoritative dictionaries, such as the Köjien and Meikyo kokugo jiten, claim particle ' $k e$ ' only attaches to -ta and $d a$ in the form of

\footnotetext{
15 Nakano et al. (2000:503) citing Tamenaga, Shunsui. 1836. Harutsugedori Vol. 3.

16 In other words, we could say some signs of epistemic modality persist in this constraint. See Hopper (1991) regarding the principle semantic persistence in morphological change.
} 
-ta kke (including datta, the copula's perfective) and da kke (Shinmura 2008 and Kitahara 2010, respectively). However, $k k e$ is now used after non-past non-copula predicates, although this shift is still underway and seen as ungrammatical by some speakers. Example (20) depicts this shift.

(20) *iku kke $>$ ? iku kke $>$ iku kke

go KKE

'Will you go? ((I don't recall. Please remind me.))'

An informal survey of native speakers of Japanese suggests that, depending on the speaker, the expression Iku kke? 'Will you go? ((I don't recall. Please remind me.))' may be regarded as 'ungrammatical', 'perhaps acceptable', or 'grammatical'. For those who, like the dictionaries discussed above, find (20) ungrammatical, -kke remains a suffix. Such speakers would need to nominalize the verb phrase and attach -kke to a copula to seek confirmation on a future intention, such as the long-standing application we see in example (21).

$$
\begin{array}{ll}
\text { iku-n } & \text { da-kke } \\
\text { go-NMLZ } & \text { COP-KKE }
\end{array}
$$

'Is it that you will go? ((I don't recall. Please remind me.))'

Speakers for whom (20) is grammatical still accept (21). Furthermore, a nascent development is the use of kke directly after predicate nominals, such as the designative ('zero-copula') examples below.

iku-n $\mathrm{kke}^{17}$
go-NMLZ KKE
'Is it that you will go? ((I don't recall. Please remind me.))'
dare $\quad \mathrm{kke}^{18}$
who $\quad \mathrm{KKE}$
'Who ((was it))? ((I don't recall. Please remind me. $))$ '
ore $\quad \mathrm{kke}$
I $\quad \mathrm{KKE}$
'((Was it)) me? ((I don't recall. Please remind me.))'

For speakers that find examples (22)-(24) grammatical in addition to (20), kke has more clearly reached the syntactic status as a sentence-final particle rather than suffix. Other SFPs seen above, such as yo, ne, and $k a$, are known to directly follow noun phrases, leaving predication to context. However, whether this use of $k k e$ becomes standardized remains to be seen.

3. Conclusions. This paper has argued for the following diachrony of auxiliary, or inflecting suffix, -kyeri $>$ sentence-final particle $k k e$.

1. Origin: $k y i$ 'having come' + stative -ari 'be'> perfect -kyeri

2. Semantic broadening: perfect $>$ perfect, epistemic modality, mirativity

3. Phonological change: -kyeri $>$-keri due to sound change $\left(y>\varnothing / C_{-} e\right)$

4. Semantic narrowing: -keri no longer indexes perfect meaning due to the primacy of its epistemic use and the newer perfect-tari

17 From a blogpost (Rana. Saigo no. Tsura tsura tawakoto the world wide, 09 Jul. 2010, https://ameblo.jp/allen3nova017/entry-10586593808.html).

18 This and the following example are from Twitter (@nawaaawin. Kiritani Mirei no danna tte dare kke? Ore kke? Twitter, 29 Jan. 2021, 10:09 a.m., https://twitter.com/niwaaawin/status/1355171135369793538). 
5. Morphological change: -keri $>-k e r u$ due to a convergence of the conclusive and adnominal finite forms of all Japanese predicate paradigms

6. Phonological reduction: $-k e r u>-k e$ due to deletion of final $-r u$ in auxiliaries

7. Phonological change: $-k e>-k k e$ due to a reanalysis of the participle's final consonant, which assimilates to the following consonant, as being part of the -ke morpheme

8. Morphosyntactic \& Semantic change: suffix $-k k e>$ sentence-final particle $k k e$; confirmed fact $>$ recollection of fact

9. Pragmatic broadening: sentence-final particle kke only following perfective $-t a$ and copula $d a>$ following predicates regardless of tense and aspect

Until the Early Modern Period, -kyeri $>-k k e$ primarily indexed the factuality of the predicate due to it being directly part of the predicator phrase's morphology. Only after the loosening of internal bonds did it come to index a recollection of the factuality of the predicate.

Although its origins and eventual loss of inflection seem to support the unidirectionality theory of morphological change, $k k e$ 's most recent shift from suffix to sentence-final particle provides an additional example of degrammaticalization (Hopper \& Traugott 2003, Norde 2009). This shift is a result of kke's diachrony. Late Middle Japanese (-keri $>$ ) -kke's affinity with perfect -tari likely has to do with the perfect's own association with recollection. The phonological reduction of auxiliary -tari to non-inflecting suffix - $t a$ led to the reanalysis of takke as $-t a+k k e$, placing the newly formed morpheme in a position to shift from indexing predicate factuality to the recollection of that fact. In declarative sentences the speaker is affirming that recollection, whereas in interrogative utterances they are questioning their own recollection, and thus looking for a reminder. This history of $k k e$ provides additional evidence that linguistic change is based on language use and sentence-final particles can develop from inflecting suffixes when the contexts in which they are used are restricted and expanded by speakers over time.

4. Further Research. In this study, I examine the phonological, morphological, syntactic, and semantic shifts in the history of Old Japanese -kyeri to Modern Japanese kke as it is used in the dominant "standard" language, or language associated with the center of political power. However, forms ranging from ke to kera are used in other present-day dialects of Japanese, some of which clearly still govern the participle, and thus are part of predicate morphology (see Sandness 1999:212-19 and Koyama 2003:332-34 for an overview of some in English). The next step in this project is to determine how the originally perfect auxiliary -kyeri developed in other regional varieties of Japanese to gain a clearer view of variation in its diachronic developments. Furthermore, more concrete data are needed on the acceptability of $k k e$ 's emergent distributional expansions.

\section{References}

Aikhenvald, Alexandra Y. 2004. Evidentiality. Oxford: Oxford University Press. Frellesvig, Bjarke. 2010. A history of the Japanese language. Cambridge: Cambridge University Press.

Hayashi, Makoto. 2012. Claiming uncertainty in recollection: A study of kke-marked utterances in Japanese conversation. Discourse Processes 49(5). 391-425.

https://doi.org/10.1080/0163853X.2012.673845. 
Hopper, Paul. 1991. On some principles of grammaticalization. In Elizabeth Closs Traugott \& Bernd Heine (eds.), Approaches to grammaticalization 1. 17-35. Philadelphia: John Benjamins.

Hopper, Paul \& Elizabeth Traugott. 2003. Grammaticalization. New York: Cambridge University Press.

Ikeya, Tomoko. 2012. Functions of the Japanese sentence-final farticles -tto and -kke: Personal domain information marked by -tto -kke and the invisible listener. Theoretical and Applied Linguistics at Kobe Shoin 15. 11-25. http://doi.org/10.14946/00000186.

Ivorski, Roumyana. 1997. The present perfect as an epistemic modal. Proceedings of SALT 7. 222-239. https://doi.org/10.3765/salt.v7i0.2795.

Kasuga, Masaji. 1942. Saidaiji-bon Konkōmyō saishōōkyō koten no kokugogakuteki kenkyū ('A linguistic study of the old glosses of the Saidaiji temple Golden light sutra'). Tōkyō: Benseisha.

Katagiri, Yōichi, Teisuke Fukui, Shōji Takahashi, \& Yoshiko Shimizu. 1994. Taketori monigatari, Ise monogatari, Yamato monogatari, Heichū monogatari: Shinpen Nihon koten bungaku zenshū 12. Tōkyō: Shōgakkan.

ke. 2020. In Nihon kokugo daijiten dainihan ('Japanese dictionary $2^{\text {nd }}$ edn.'). https://japanknowledge.com (12 May 2020).

Kitahara, Yasuo. 2010. Meikyō kokugo jiten. Tōkyō: Taishukan Shoten.

Kojima, Noriyuki, Masatoshi Kinoshita \& Haruyuki Tōno. 1994. Man'yōshū 1: Shinpen Nihon koten bungaku zenshū 6. Tōkyō: Shōgakkan.

Koyama, Wataru. 2003. Language and its double: A critical history of dialects, languages, and metalanguages in Japan. Chicago: The University of Chicago dissertation.

Lau, Monica Laura \& Johan Rooryck. 2017. Aspect, evidentiality, and mirativity. Lingua 186187. 110-119. https://doi.org/10.1016/j.lingua.2016.11.009.

Ma, Yingrui. 2017. Nihongo gimonbun no tōgo goyōronteki kenkyū ('A syntactic-pragmatic study of Japanese interrogative sentences'). Hokkaidō: Hokkaido University dissertation.

Matahira, Emiko. 1996. Shūjoshi no kenkyū: 'kke' no kinō ('A study of sentence-final particles: The functions of "kke"). Tsukuba Nihongo kenkyū 1. 21-33.

Martin, Samuel. 1975. A reference grammar of Japanese. New Haven, CT: Yale University Press.

Muromachi Jidaigo Jiten Henshū Iinkai. 1985. Jidaibetsu kokugo daijiten Muromachi jidai hen ('A periodized dictionary of Japanese: Muromachi period Japanese') 2. Tōkyō: Sanseidō.

Nakamura, Michio. 1985. Tōkyōgo no seikaku ('The character of the language of Tokyo'). Tōkyō: Kawata Shobō.

Nakano, Mitsutoshi, Kazuya Jinbo, \& Ai Maeda. 2000. Sharebon, kokkeibon, ninjōbon: Shinpen Nihon koten bungaku zenshū 80. Tōkyō: Shōgakkan.

Norde, Muriel. 2009. Degrammaticalization. New York: Oxford University Press.

Okada, Richard. 1991. Figures of resistance: Language, poetry and narrating in The tale of Genji and other mid-Heian texts. Durham: Duke University Press.

Quinn, Charles. 1983. Ōchō sanbun no gyōshūsei: Jisei to asupekuto o chūshin ni ('Cohesion in Heian vernacular prose: The role of mood, tense, and aspect'). Proceedings of the 7th International Conference on Japanese Literature in Japan. 9-29.

Sandness, Karen E. 1999. The evolution of the Japanese past and perfective suffixes. Ann Arbor, MI: The University of Michigan Press. 
Sauerland, Uli \& Kazuko Yatsushiro. 2017. Remind-me presuppositions and speech-act decomposition: Evidence from particles in questions. Linguistic Inquiry 48(4). 651-677. https://doi.org/10.1162/LING_a_00257.

Shibutani, Katsumi. 1999. Bunmatsushi 'ke': Mittsu no taikei ni okeru taishō kenkyū ('Sentencefinal particle 'ke': A comparative study of three linguistic varieties'). Kindaigo kenkyū 10. 205-230.

Shinmura, Izuru. 2008. Kōjien. Tōkyō: Iwanami Shoten.

Shinzato, Rumiko. 1991. Where do temporality, evidentiality and epistemicity meet? A comparison of Old Japanese -ki and -keri with Turkish -di and -miş. Gengo kenkyū 3. 2557. https://doi.org/10.11435/gengo1939.1991.25.

takke. 2020. In Nihon kokugo daijiten dainihan ('Japanese dictionary $2^{\text {nd }}$ edn.'). https://japanknowledge.com (12 May 2020).

Vovin, Alexander. 2009. A descriptive and comparative grammar of Western Old Japanese part 2: Adjectives, verbs, adverbs, conjunctions, particles, postpositions. Kent, UK: Global Oriental.

Yamaguchi, Yoshinori \& Takamitsu Kōnoshi. 1997. Kojiki: Shinpen Nihon koten bungaku zenshū 1. Tōkyō: Shōgakkan.

Yanase, Kazuo. 1964. Kōchü Kamo no Chōmei zenshū ('The complete works of Kamo no Chōmei with annotations'). Tōkyō: Kazama Shobō.

Yoshida, Kanehiko. 1971. Gendaigo jodōshi no shiteki kenkyū ('A historical study of modern Japanese auxiliaries'). Tōkyō: Meiji Shoin. 